\title{
Five-year follow-up of islet cell antibodies in Type 2 (non-insulin-dependent) diabetes mellitus
}

\author{
L. Niskanen ${ }^{1}$, J. Karjalainen ${ }^{3}$, H.Sarlund ${ }^{1}$, O.Siitonen ${ }^{1}$ and M. Uusitupa ${ }^{2}$ \\ ${ }^{1}$ Department of Medicine, University of Kuopio, Kuopio, ${ }^{2}$ Department of Clinical Nutrition, University of Kuopio, Kuopio and \\ ${ }^{3}$ Department of Paediatrics, University of Oulu, Oulu, Finland
}

\begin{abstract}
Summary. The aim was to study the frequency and appearance of cytoplasmic islet cell antibodies in relation to impairment of insulin secretory capacity and some clinical characteristics in a representative group of middle-aged (45-64 years) patients with Type 2 (non-insulin-dependent) diabetes mellitus ( 70 male, 63 female) at the time of diagnosis and at five-year follow-up. Non-diabetic control subjects (62 male, 82 female) were similarly examined at five-year intervals. At the baseline five out of $133(3.8 \%)$ diabetic patients were positive for conventional and four (3.0\%) for complement-fixing islet cell antibodies. Ten patients had become positive by the second screening for conventional antibodies and six for complement-fixing antibodies, but none showed negative conversion. Two non-diabetic subjects $(1.5 \%)$ became antibody positive during the follow-up. Insulin treatment was started during the follow-up for four out of 15
\end{abstract}

$(27 \%)$ conventional antibody positive and for one out of 121 $(0.8 \%)$ antibody negative diabetic patients $(p=0.001)$. The sensitivity of the positive conventional and complement-fixing antibody for identifying patients who developed an impairment of insulin secretory capacity (post-glucagon C-peptide $\leqq 0.60 \mathrm{nmol} / 1$ at 5 -year) was $75 \%$. The respective specificity was $90 \%$ and the positive predictive values were highest in the case of high positivity $(50 \%)$. The negative predictive value of antibody positivity was close to $100 \%$. In conclusion, islet cell antibody positivity in patients classified as Type 2 was persistent during the follow-up and predicted the future development of insulin deficiency especially in those patients with high or increasing antibody titres.

Key words: Type 2 (non-insulin-dependent) diabetes mellitus, insulin secretion, islet cell antibodies.
Failure of treatment with diet and oral hypoglycaemic agents is a common clinical experience in patients with Type 2 (non-insulin-dependent) diabetes increasing with the duration of the disease [1]. The causes of this failure are yet unknown, but the deterioration of Beta-cell function can explain the persistent hyperglycaemia despite adequate diet and drug therapy in some patients clinically classified as having Type 2 diabetes. A subgroup of maturity-onset diabetic subjects positive for islet cell antibodies (ICA) may have an atypical disease and have insulin prescribed. Later some, but not all these individuals may develop typical Type 1 (insulin-dependent) diabetes $[2,3]$. However, at present there is no uniform agreement as to how to classify these patients correctly. Studies on ICA in patients with Type 1 diabetes have shown the vanishing nature of ICA [4-8] in contrast to that of other autoimmune diseases. The mechanism of this evanescent nature of ICA in patients with youth-onset Type 1 diabetes is unknown, but it may be associated with the rapid loss of Beta cells. Previous studies on the significance of ICA and their occurrence in Type 2 diabetic patients have been done on patients recruited from endocrine or diabetes clinics $[2,3,9,10]$, but there are no long-term studies on the time course of ICA in Caucasian patients with apparent Type 2 diabetes. Among these patients ICA are generally of low level [9], but on the other hand ICA have been detected in a small proportion of non-diabetic subjects $[2,4$, $11,12]$. We report the presence of ICA in relation to impairment of insulin secretory capacity and some clinical characteristics in a representative group of Type 2 diabetic patients studied at the time of diagnosis and after five years, and in non-diabetic control subjects.

\section{Subjects and methods}

\section{Subjects}

The original study population consisted of 133 patients aged 45 to 64 years with newly diagnosed Type 2 diabetes and 144 randomly selected non-diabetic control subjects of the same age group. The collection of both groups was carried out during the period 1 May 1979 


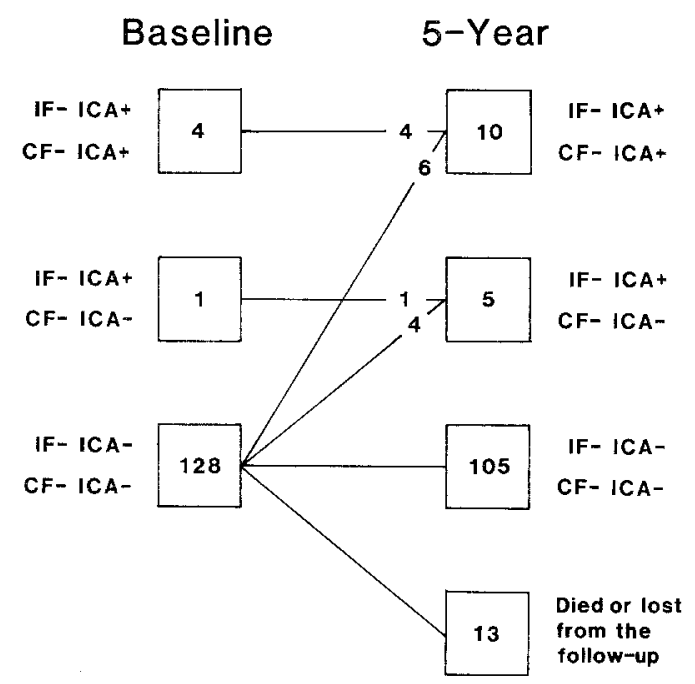

Fig. 1. Flow diagram on the course of islet cell antibodies (IF-ICA + conventional islet cell antibody - positive, CF-ICA + complement fixing islet cell antibody-positive) in the diabetic patients during the follow-up

to 31 December 1981. Both groups were recruited from a defined area of 180,000 inhabitants in the county of Kuopio in Eastern Finland. Approval for the study has been given by the Ethics Committee of Kuopio University Central Hospital. Informed consent was given by all subjects studied.

The diabetic patients ( 70 male, 63 female) were referred to the study by general practitioners working in community health centres in the survey area. The diagnosis of diabetes was primarily made in the clinical setting and was confirmed by an oral glucose tolerance test using diagnostic criteria recommended by the World Health Organization (WHO) Expert Committee on Diabetes Mellitus [13]. Subjects whose fasting blood glucose had exceeded $7.0 \mathrm{mmol} / \mathrm{l}$ for more than six months as well as subjects with secondary diabetes, hypo- or hyperthyroidism, alcoholism, renal insufficiency, overt carcinoma or those in institutional care were not eligible for the study. All the diabetic patients were non-ketotic at the time of diagnosis. The non-diabetic control population of the same age group ( 62 male, 82 female) was selected randomly from the population register using random number tables. The formation, representativeness and methods of the baseline examination have been described previously in detail [14]. The five-year examination of newly diagnosed diabetic patients and non-diabetic control subjects was carried out between August 1985 and January 1986.

Eighty diabetic patients participated in the diet intervention study lasting one year [15]. Otherwise they were referred to the primary care setting after the baseline examination and the same applying also for the participants of the diet intervention study after its completion.

\section{Methods}

Medical history. The examinations of the five-year study were carried out, when appropriate, according to the same methods and by the same personnel as in the baseline study. The history of cardiovascular and other significant diseases and the use of drugs were registered at both examinations. The site of diabetes management, drugs for treatment of diabetes and the duration of different modes of treatment for diabetes (diet, oral hypoglycaemic agents, insulin) was ascertained from the medical records at the five-year examination. The family history of diabetes of first-degree relatives was obtained at the baseline study.

Anthropometric measurements. Body mass index was calculated as: body weight $(\mathrm{kg}) /$ height ${ }^{2}\left(\mathrm{~m}^{2}\right)$. At the five-year examination the cir- cumference of the waist was measured from the level of the umbilicus in the neutral breathing position and the pelvis circumference was measured at the level of trochanter major.

\section{Biochemicalmethods}

A $75 \mathrm{~g}$ oral glucose tolerance test was performed. Blood samples for plasma insulin at both examinations and C-peptide at the five-year examination were collected into chilled tubes in a fasting state before and 1-2 h after an oral glucose load.

At the baseline study glucose was determined by a glucose oxidase method Glox (Kabi AB, Stockholm, Sweden). At the five-year examination glucose was determined by a glucose dehydrogenase method (Merck Diagnostica, Darmstadt, FRG) from plasma samples.

At both examinations serum insulin was determined by a radioimmunoassay (M 8309, Novo, Copenhagen, Denmark at baseline; Phasedeph, Pharmacia Diagnostics, Uppsala, Sweden at the five-year examination). The detection limit of the assays was $2.5 \mathrm{mU} / 1$ and coefficient of variation below $5.0 \%$. Upon comparison Phasedeph gave approximately $7 \%$ higher values than Novo-antiserum $(r=0.952, y=0.930 x+2.55)$.

Plasma C-peptide was determined by radioimmunoassay (Antiserum M1230, Novo) in connection with an oral glucose tolerance test at the five-year examination.

C-peptide response to $1 \mathrm{mg}$ of glucagon i.v. at the five-year examination was determined according to Faber and Binder [16] in all the insulin-treated patients $(n=5)$ and also in those diabetic patients treated with diet or oral hypoglycaemic drugs whose maximal C-peptide response in an oral glucose tolerance test remained under $1.00 \mathrm{nmol} / /(n=9)$.

Glycated haemoglobin $\mathrm{A}_{1}\left(\mathrm{Hb}_{1}\right)$ (normal range: $\left.5.5-8.5 \%\right)$ at five-year examination was determined by column chromatography (Quik-Sep Fast Hemoglobin Test System, Isolab, Akron, Ohio, USA) after incubation in $0.9 \% \mathrm{NaCl}$ solution for $12 \mathrm{~h}$.

\section{Islet cell antibodies}

The methods for detecting conventional or immunofluorescent (IFICA) and complement-fixing (CF-ICA) $[17,18]$ cytoplasmic islet cell antibodies were exactly the same as published elsewhere in more detail [19]. ICA were determined in the Research Laboratory of the Department of Paediatrics, University of Oulu, Oulu, Finland, (principal investigator Dr. J.Karjalainen). Samples of $2 \mathrm{ml}$ serum were drawn for the analyses. The assay was performed on $4 \mu \mathrm{m}$ thick sections of human blood group 0 pancreas according to the protocol proposed by the International Workshops on the Standardization of the Islet Cell Antibody Assay [20]. The substrate was obtained from a 14-year-old cadaveric kidney donor, and was macroscopically well preserved. Time of warm ischaemia was less than $1 \mathrm{~min}$. The substrate was precooled in liquid nitrogen and kept at $-20^{\circ} \mathrm{C}$ until the analyses were performed. The final positive end-point dilution of the international standard serum is considered to represent 80 Juvenile Diabetes Foundation (JDF) units. The standard curve was established and the results expressed in JDF-units relative to the endpoint dilution of each sample. In the present study the same standard serum was used to obtain the standard curves for both IF-ICA and CF-ICA. The standard serum gave the end-point dilution of $1: 32$ for IF-ICA and 1:4 for CF-ICA, and the thresholds for positivity were 2.5 and $20 \mathrm{JDF}$-units, respectively. Linear extrapolation from the standard curve was used to calculate extraordinarily high ( $\geqq 80$ JDF-units) levels of both IF-ICA and CF-ICA. The results at the low end were expressed by a three step evaluation; those at 5 JDF-units, those at 2.5 JDF-units and as negative. Our laboratory has participated in the international comparison since 1987. The results in the recent workshop held in Jerusalem in March 1990 gave a sensitivity of $100 \%$, a specificity of $98 \%$ and a validity of $98 \%$ for the assay. The 
disease sensitivity and specificity were $65 \%$ and $98 \%$, respectively, and the positive predictive value of the test in ascertained prediabetic or diabetic subjects $95 \%$. The detection limit for IF-ICA in the assay was $2.5 \mathrm{JDF}$-units based on 109 samples determined for the Workshop.

\section{Statistical analysis}

All values are given as mean \pm SEM or frequency tables. Differences between the group means were assessed by the analysis of covariance (ANCOVA), chi-squared or Fischer's test. Serum insulin was analysed after logarithmic transformation. The sensitivity of the ICA-test is the percentage of ICA-positive subjects out of those who developed the impairment of Beta-cell function (post-glucagon $\mathrm{C}$ peptide level $\leqq 0.60 \mathrm{nmol} / \mathrm{l}$ ). The specificity of the ICA-test corresponds to the percentage of those individuals not developing Betacell impairment who could be identified by the negative test results. The positive predictive value of the ICA-test represents the calculated likelihood of an individual with a positive test result developing Beta-cell impairment. The negative predictive value of the ICA-test indicates the likelihood of a subject with a negative result to remain unaffected. All the analyses were carried out in the Computing Centre of the University of Kuopio by using the Statistical Package for Social Sciences (SPSS).

\section{Results}

Eight diabetic patients (five male, three female) and two non-diabetic control subjects (one male, one female) died during the follow-up. Five diabetic patients (two male, three female) and five control subjects (one male, four female) were lost from the five-year examination. The mean age of diabetic patients at the baseline was higher than that of the control subjects $(54.7 \pm 0.7$ vs $52.9 \pm 0.7$ years for males, $p<0.05 ; 57.1 \pm 0.7$ vs $54.3 \pm 0.6$ years, $p<0.01$ for females).

Similar to the baseline examination both diabetic males $\left(28.4 \pm 0.5 \mathrm{~kg} / \mathrm{m}^{2}\right)$ and females $\left(28.7 \pm 0.7 \mathrm{~kg} / \mathrm{m}^{2}\right)$ showed a higher body mass index than non-diabetic males $\left(26.4 \pm 0.4 \mathrm{~kg} / \mathrm{m}^{2}, p<0.01\right)$ and females $\left(27.7 \pm 0.6 \mathrm{~kg} / \mathrm{m}^{2}\right)$, although at the five-year examination the difference was not statistically significant in females.

At the baseline examination all the diabetic patients were on diet only and none required insulin at least during the first three months after the diagnosis. Among the diabetic patients participating in the five-year examination, $35(56 \%)$ of males and $23(40 \%)$ of females were treated with diet only and $27(42 \%)$ of males and $30(52 \%)$ of females were on oral drugs. Insulin treatment had been started in one male $(2 \%)$ and four females $(7 \%)$. On an average the metabolic control was poor both in diabetic males and females. The mean fasting plasma glucose and $\mathrm{HbA}_{1}$ levels at the five-year examination were $11.5 \pm 0.5 \mathrm{mmol} / 1$ and $8.9 \pm 0.3 \%$ for males and $12.4 \pm 0.5 \mathrm{mmol} / 1$ and $9.6 \pm 0.3 \%$ for females.

Figure 1 shows the flow diagram of the ICA-status in the diabetic subjects both at the baseline and at the fiveyear examination. At the baseline examination 5 out of $133(3.8 \%)$ diabetic patients (three male, two female)

Table 1. Clinical characteristics of the diabetic patients according to the islet cell antibody (ICA) status and non-diabetic subjects

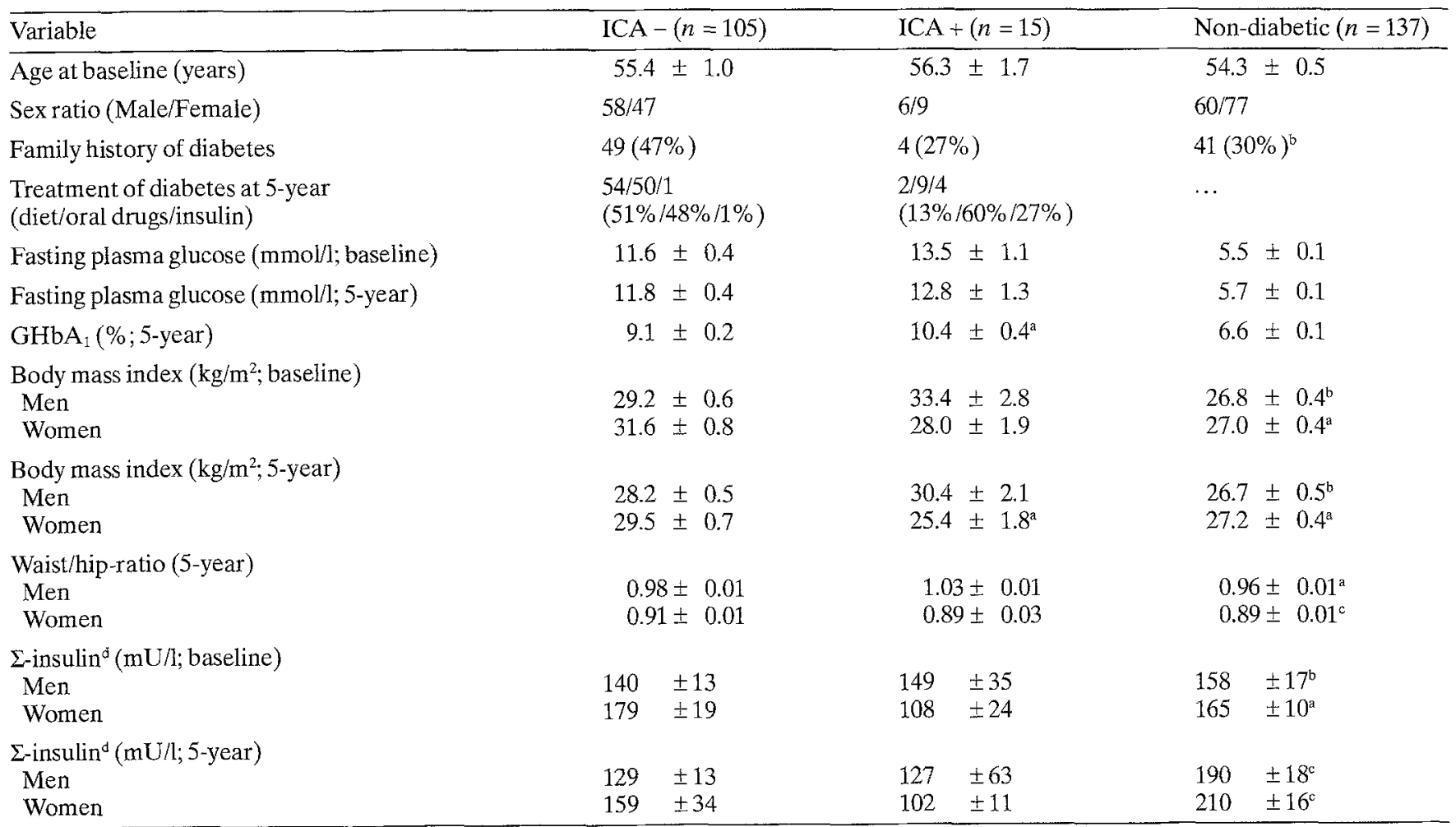

${ }^{a} p<0.05,{ }^{b} p<0.01,{ }^{c} p<0.001$ as compared to ICA-negative diabetic patients (ANCOVA controlling for age and sex and also for body mass index in insulin analyses) or chi-squared test. The com- parison of control subjects to ICA-positive diabetic patients described in text. ${ }^{\triangle}$ Sum of fasting, $1 \mathrm{~h}$ and $2 \mathrm{~h}$ insulin levels 
Table 2a. The age, sex and treatment of diabetes and conventional islet cell antibody (IF-ICA) and complement-fixing islet cell antibody (CF-ICA) levels in Juvenile Diabetes Foundation-units in IFICA and/or CF-ICA-positive diabetic patients in group I (negative at baseline, positive at five-year), group II (positive at both examinations), group III (IF-ICA positive at five-year), group IV (IF-ICA positive at both examinations) and group V (control subjects, ICApositive at five-year)

\begin{tabular}{|c|c|c|c|c|c|c|c|}
\hline & $\begin{array}{l}\text { Age (years) } \\
\text { baseline }\end{array}$ & Sex & $\begin{array}{l}\text { Treatment } \\
\text { at 5-year }\end{array}$ & $\begin{array}{l}\text { IF-ICA } \\
\text { baseline }\end{array}$ & $\begin{array}{l}\text { CF-ICA } \\
\text { baseline }\end{array}$ & $\begin{array}{l}\text { IF-ICA } \\
\text { 5-year }\end{array}$ & $\begin{array}{l}\text { CF-ICA } \\
\text { 5-year }\end{array}$ \\
\hline \multicolumn{8}{|c|}{ Group I } \\
\hline 1 & 62 & Female & Oral drugs & 0 & 0 & 5 & 20 \\
\hline 3 & 64 & Male & Diet & 0 & 0 & 20 & 20 \\
\hline 4 & 60 & Female & Insulin & 0 & 0 & 80 & 80 \\
\hline 5 & 54 & Male & Insulin & 0 & 0 & 2.5 & 20 \\
\hline 1 & 46 & Male & Oral drugs & 20 & 20 & 20 & 20 \\
\hline 2 & 57 & Female & Oral drugs & 5 & 20 & 2.5 & 20 \\
\hline 3 & 54 & Female & Insulin & 80 & 40 & 160 & 160 \\
\hline 4 & 47 & Male & Oraldrugs & 40 & 40 & 80 & 160 \\
\hline \multicolumn{8}{|c|}{ Group III } \\
\hline \multicolumn{8}{|c|}{ Group IV } \\
\hline 1 & 49 & Male & Oral drugs & 5.0 & 0 & 2.5 & 0 \\
\hline \multicolumn{8}{|c|}{ Group V } \\
\hline 1 & 63 & Female & $\ldots$ & 0 & 0 & 2.5 & 0 \\
\hline 2 & 56 & Female & $\ldots$ & 0 & 0 & 10 & 20 \\
\hline
\end{tabular}

were IF-ICA-positive and four out of $133(3.0 \%$; two male, two female) also CF-ICA-positive. Altogether ten diabetic patients (three male, seven female) from the baseline population became IF-ICA-positive and six (three male, three female) CF-ICA-positive. None of the ICApositive diabetic patients at the baseline examination was ICA-negative at the five-year examination and none showed exclusively CF-ICA-positivity. The frequency of IF-ICA-positive diabetic patients at the five-year examination was thus 15 out of $115(13 \%)$ and that of CF-ICApositive subjects 10 out of $115(8.7 \%)$.

At the baseline examination none of the control subjects was ICA-positive, but at the five-year examination two female control subjects $(1.5 \%)$ were ICA-positive; one IF-ICA-positive only and the other both IF-ICA and CF-ICA-positive. Both had normal glucose tolerance at the baseline according to WHO criteria [13], but at the five-year examination two had impaired glucose tolerance.

Table 1 shows the clinical and biochemical characteristics of control subjects and the diabetic patients according to the ICA-status at the five-year examination. There was no significant difference in the mean age, sex distribution or the family history of diabetes between the diabetic groups. Fasting plasma glucose both at the baseline and at the five-year and $\mathrm{HbA}_{1}$ at the five-year examination were higher in ICA-positive diabetic patients than in ICA-negative subjects. Insulin treatment was started during the follow-up for 4 out of $15(27 \%)$ of ICA-positive patients and for 1 out of $121(0.8 \%$; $p=0.001)$ IF-ICA-negative patients. The body mass index was lower in female ICA-positive diabetic subjects both at the baseline $(p=0.08)$ and at the five-year examination $(p<0.05)$ but in male diabetic subjects no significant difference was found in this respect. The control subjects of both sexes had at both examinations a lower mean body mass index than the ICA-negative diabetic patients $(p<0.05-0.001)$, but the body mass index in female control subjects was about the same at baseline as in ICA-positive diabetic patients, whereas ICA-positive male diabetic patients were more obese than respective control subjects $(p<0.05)$. There was no significant difference between waist/hip-circumferenceratio between the diabetic groups. In control subjects of both sexes the waist/hip-circumference ratio was lower $(p<0.05)$ than in ICA-negative diabetic patients.

The insulin response (Table 1) to an oral glucose load (sum of the fasting, 1 and $2 \mathrm{~h}$ plasma insulin levels) tended to be lower in ICA-positive than in ICA-negative female diabetic subjects at both examinations $(p<0.05$ at the baseline, $p=0.08$ at five year) but no difference was found in diabetic males in this respect. The oral glucose tolerance test was not performed at the five-year examination for those diabetic patients who had insulin treatment.

More detailed clinical characteristics of ICA-positive subjects are shown in Tables $2 \mathrm{a}$ and $2 \mathrm{~b}$. The subjects are divided on the basis of the time courses of IF-ICA and CFICA into five groups (Table $2 a$ ). Six patients initially ICA-negative became both IF-ICA and CF-ICA-positive during the follow-up (group I). Patient 4 had high ICAlevels and also reduced C-peptide response to i.v. glucagon $(0.23 \mathrm{nmol} / 1)$, the insulin treatment had been started 39 months from the diagnosis. Patient 6 had an undetectable C-peptide level after glucagon stimulation and in- 
Table 2b. The body mass index (BMI), fasting plasma glucose (fp-gluc), 2-h plasma glucose (2-h p-gluc; in group V only), $\Sigma$-insulin (sum of fasting $1 \mathrm{~h}$ and $2 \mathrm{~h}$ insulin levels) at baseline and at five-year and maximal C-peptide at oral glucose tolerance test or after glucagon ${ }^{\mathrm{a}}$

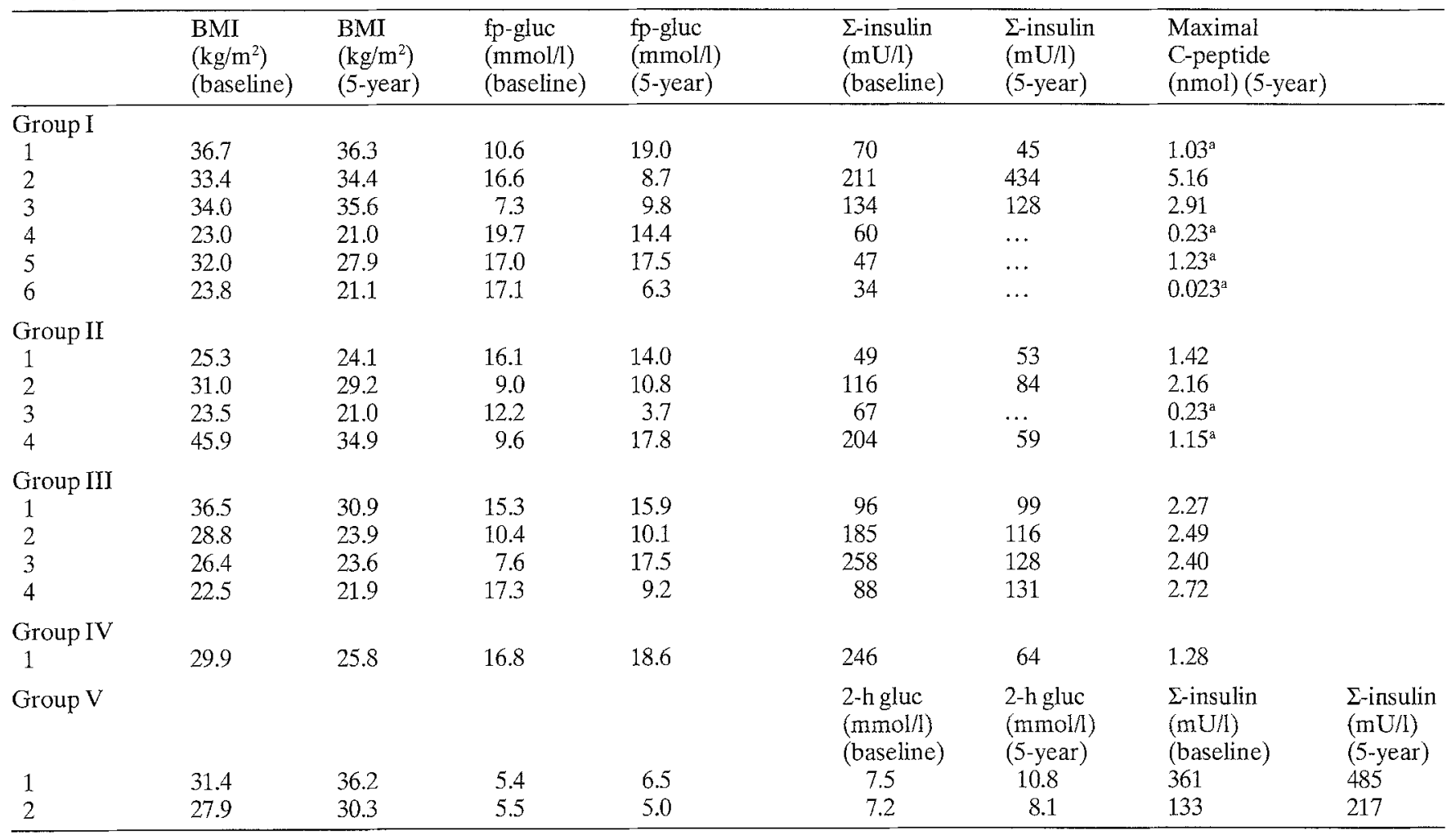

sulin treatment was started 53 months from the diagnosis. Among the subjects in group II (IF-ICA and CF-ICApositive at both examinations) one diabetic female (patient 3) with insulin treatment had low C-peptide response to i.v. glucagon $(0.23 \mathrm{nmol} / \mathrm{l})$ and she had higher ICA-levels at the five-year examination compared to baseline; the insulin treatment had been started six months from diagnosis. The history of patient 4 in group II is remarkable. At the time of diagnosis he was morbidly obese, at the five-year examination he had lost weight, but was still obese, and he had higher ICA-levels and lower insulin response than at baseline, but post-glucagon C-peptide showed no evident insulin deficiency. However, 10 months after the five-year examination he was referred to our clinic for continuing hyperglycaemia and weight loss, post-glucagon C-peptide measured by the same method was now $0.73 \mathrm{nmol}$ and insulin treatment was started. In group III the patients were ICA-negative at the time of diagnosis, but IF-ICA-positive (of low level) at the five-year examination. Group IV (IF-ICA-positive at both examinations) comprises one male with lower body mass index and insulin response to oral glucose load at the five-year than at baseline, but post-glucagon C-peptide showed no evident Beta-cell impairment. Group V comprises those non-diabetic control subjects who became ICA-positive during the follow-up.

The sensitivity of the positive IF-ICA and CF-ICA for identifying patients who developed insulin-deficiency (post-glucagon C-peptide $<0.60 \mathrm{nmol} / \mathrm{l}$ ) was $75 \%$ (Table 3) irrespective of the ICA-levels. The specificity of both tests was $90 \%$. The positive predictive values were highest $(50 \%)$ in the case of persistent high positivity ( $\geqq 40$ JDF-Units). The negative predictive value for both tests was close to $100 \%$ (Table 3 ).

\section{Discussion}

Nearly all previous studies on ICA in Caucasian patients with Type 2 diabetes have been cross-sectional or shortterm and performed on patients drawn from endocrine or diabetes clinics and thus included a large number of patients with normal body weight and polyendocrinopathies $[2,3,9,10]$. Our study population was collected from a defined area and age group. We have also studied nondiabetic control subjects, who were drawn randomly from the population register. Furthermore, $97 \%$ of diabetic patients showed preserved insulin secretory capacity at the five-year examination showing their correct classification as non-insulin-dependent. Although all newly diagnosed patients of the study could not be recruited originally into the present study aimed to evaluate the occurrence of cardiovascular complications and risk factors in patients with newly diagnosed Type 2 diabetes [14] our study population was considered representative of newly diagnosed Type 2 diabetic patients of this age group [21]. The true number of patients receiving insulin therapy could not be higher in this age group because patients requiring insulin treatment in the study area are referred to our hospital from the local health centres and private practitioners. 
Table 3. Sensitivity, specificity and positive and negative predictive values of the positive conventional islet cell antibody (IF-ICA +) and complement-fixing islet cell antibody $(\mathrm{CF}-\mathrm{ICA}+)$ tests with respect to the development of insulin deficiency (post-glucagon $\mathrm{C}$ peptide $\leqq 0.60 \mathrm{nmol} / 1)$ in diabetic patients

\begin{tabular}{llll}
\hline Parameter & IF-ICA + & CF-ICA + & $\begin{array}{l}\text { IF/CF-ICA } \\
\text { levels } \geqq 40 \\
\text { IDF-units } \\
(n=3)\end{array}$ \\
\hline Sensitivity & $(n=15)$ & $(n=10)$ & $75 \%$ \\
Specificity & $90 \%$ & $94 \%$ & $98 \%$ \\
Positive predictive value & $20 \%$ & $30 \%$ & $50 \%$ \\
Negative predictive value & $99 \%$ & $99 \%$ & $98 \%$ \\
\hline
\end{tabular}

The ICA-measurements did not have any influence on the choice of diabetes treatment as ICA-determinations were done in a separate laboratory based on coded samples from the baseline and the five-year examination.

The prevalence of ICA in patients with Type 2 diabetes has ranged in previous studies from $5-15 \%[2,4,9-11,22]$ and in non-diabetic subjects they are found in less than $1 \%$ $[2,4,9,11,12]$, but in older studies ICA-levels were not expressed in JDF-units. These figures are about the same as in our study population. Interestingly, in our patients the ICA were persistent over the five-year period and the increase in ICA levels was found in two patients already positive at the baseline. The fluctuating or transient nature of ICA [23] may explain this behaviour. However, it is also possible that in this age group ICA are more persistent because Beta-cell damage may be more limited or slowly progressive than in younger patients with Type 1 diabetes. The finding of ICA persistence once they appear has been underlined recently in subjects prone to Type 1 diabetes [24] and among healthy children and adolescents in a large Finnish study [19]. However, in a Japanese follow-up study of 28 in the "non-insulin-dependent stage of" Type 1 diabetic middle-aged patients, ten initially ICA-positive diabetic patients became ICA-negative and their Beta-cell function improved, whereas the remaining 18 with persistent ICA-positivity showed deteriorating Beta-cell function and seven progressed to insulin-dependency [25].

The marked increase in the IF-ICA as well as CF-ICA levels over the five-year period in four of our patients, of whom three showed (and the fourth eventually) Beta-cell impairment indicates that they probably had adult-onset Type 1 diabetes characterised by a remarkably slow clinical course to insulin-dependency. Previous studies have suggested that insulin-treatment will be required in most ICA-positive Type 2 diabetic patients within five years, but according to the present results the development of insulin deficiency may require even longer follow-up. Groop et al. found that C-peptide response to glucagon was diminished only in those ICA-positive patients with "secondary drug failure" who were heterozygous for HLA-DR3/DR-4 [26]. On the other hand, Japanese patients with persistent ICA-positivity and deterioration of Beta-cell function showed high frequency of HLA-DR-4 and HLA-Bw-54 positivity [25]. It is possible that genetic predisposition among ICA-positive patients facilitates the impairment of Beta-cell function, but in our study HLAdeterminations were not done.

The majority of childhood-onset Type 1 diabetic patients are IF-ICA-positive at the time of diagnosis [27]. It is known, that when Type 1 diabetes begins in adulthood insulin treatment may not be required immediately [28], but information about the clinical characteristics of adultonset Type 1 diabetes is relatively scanty. Recently, a large Finnish study compared the characteristics between childhood-onset and adult-onset Type 1 diabetes [29]. Adult Type 1 diabetic patients had a longer symptomatic period before diagnosis and better preserved Beta-cell function, but the frequency of ICA was comparable to those with childhood-onset diabetes mellitus.

Female ICA-positive diabetic patients tended to be leaner than ICA-negative or control subjects, but in males no difference was found. Type 1 and Type 2 diabetic patients also have differences in body fat distribution, the latter group being characterised by central or upper body obesity [30]. However, in this regard no statistically significant differences in waist/hip-ratio was seen between the diabetic groups, whereas control subjects had lower waist/hip-ratio than ICA-negative diabetic patients.

The ICA-positive patients tended to be more hyperglycaemic and have lower insulin responses to oral glucose at both examinations than ICA-negative patients. At the five-year examination the oral glucose tolerance test was not performed on patients having insulin treatment. The results of this test in these insulin-treated patients might have confirmed the differences in insulin levels between ICA-positive and ICA-negative diabetic patients. The lowered insulin response to oral glucose in ICA-positive patients has also been observed earlier [31].

The sensitivity and specificity of IF- and CF-ICA at the five-year examination in detecting Beta-cell impairment was quite high (75-98\%). The positive predictive value was highest $(50 \%)$ with clearly elevated ICA-levels and actually those patients with high ICA levels were likely to become insulin-dependent during the observation period. The negative predictive value of ICA was close to $100 \%$. However, as ten diabetic patients were initially ICA-negative, a single measurement may show lower sensitivity than in our study.

The higher prevalence of ICA demonstrated in patients with Type 2 diabetes as compared to non-diabetic subjects suggests that ICA are not coincidental in the former and supports the concept of clinical and immunological heterogeneity in Type 2 diabetes. Do all these ICApositive patients have "latent Type 1 diabetes"? We did not find any consistent differences in the clinical characteristics between ICA-positive and -negative patients. Nevertheless, as ICA-positive Type 2 diabetic patients tended to be more hyperglycaemic and have lower insulin responses than ICA-negative patients repeated ICAmeasurements may help to identify patients likely to benefit from early insulin treatment. In conclusion, ICApositivity in diabetic patients classified as Type 2 was persistent during the follow-up and predicted the development of insulin-deficiency especially in those patients with high or increasing antibody titres. 
Acknowledgements. This study was financially supported by the grants from the Yrjö Jahnsson Foundation, the Finnish Foundation of Diabetes Research, Nordisk Insulin Fond, Denmark, Helena Vuorenmies Foundation, Orion Corporation Research Foundation, Finnish Medical Foundation and North Savo Regional Fund of the Finnish Cultural Foundation. The skillful secretarial assistance of Ms. E-M. Oittinen in the preparation of the manuscript is gratefully acknowledged.

\section{References}

1. Groop LC, Pelkonen R, Koskimies S, Bottazzo GF, Doniach D (1986) Secondary failure to treatment with oral antidiabetic agents in non-insulin dependent diabetes. Diabetes Care 9: 129-133

2. Irvine WJ, McCallum CJ, Gray RS, Campbell CJ, Duncan LJP, Farquhar JW, Vaughan H, Morris PJ (1977) Pancreatic islet-cell antibodies in diabetes correlated with the duration and type of diabetes, coexistent autoimmune disease, and HLA type. Diabetes 26: 138-147

3. Groop LC, Bottazzo GF, Doniach D (1986) Islet cell antibodies identify latent Type 1 diabetes in patients aged $35-75$ years at diagnosis. Diabetes 35:237-241

4. Lendrum R, Walker G, Cudworth AG, Theophanides C, Pyke DA, Bloom A (1976) Islet cell antibodies in diabetes mellitus. Lancet II: $1273-1276$

5. Pujol-Borrell R, Richart C, Martin C, Martinez-Vacquez JM, Bottazzo GF (1978) Islet cell antibodies in Spanish diabetics. Lancet I: 268-269

6. Madsbad S, Bottazzo GF, Cudworth AG, Dean BM, Faber OK, Binder C (1980) Islet-cell antibodies and beta-cell function in insulin-dependent diabetics. Diabetologia 18: 45-47

7. Mustonen A, Knip M, Huttunen N-P, Puukka R, Käär M-L, Åkerblom HK (1984) Evidence of delayed beta-cell destruction in Type 1 (insulin-dependent) diabetic patients with persisting complement-fixing islet cell antibodies. Diabetologia 27: 421-426

8. Bruining GJ, Molenaar J, Tuk CW, Lindeman J, Bruining HA, Marner B (1984) Clinical time-course and characteristics of islet cell cytoplasmic antibodies in childhood diabetes. Diabetologia 26: $24-29$

9. DelPrete GF, Betterle C, Padovan D, Erle G, Toffolo A, Bersahi $G$ (1977) Incidence and significance of islet-cell autoantibodies in different types of diabetes mellitus. Diabetes 26:909-915

10. Jennings AM, Spencer KM, Dean BM, Wilson RM, Bottazzo GF, Ward JD (1989) Islet cell antibodies and insulin autoantibodies in patients treated with oral hypoglycaemic agents. Diab Med 6: 434-439

11. Rodger B, Whittingham S, Martin FIR, Hawkins BR, Dawkins RL, Welborn TA (1980) A population survey of pancreatic islet cell antibodies. Clin Exp Immunol 39: 125-129

12. Notsu K, Oka N, Note S, Nabeya N, Kuno S, Sakurami T (1985) Islet cell antibodies in the Japanese population and subjects with Type 1 (insulin-dependent) diabetes. Diabetologia 28: 660-662

13. WHO Expert Committee (1980) Second report on diabetes mellitus. Geneva, World Health Organization. (Technical Report Series 646)

14. Uusitupa M, Siitonen O, Aro A, Pyörälä K (1985) Prevalence of coronary heart disease, left ventricular failure and hypertension in middle-aged newly diagnosed Type 2 (non-insulin-dependent) diabetic subjects. Diabetologia 28: 22--27

15. Korhonen T, Uusitupa M, Aro A, Kumpulainen T, Siitonen O, Voutilainen E, Pyörälä K (1987) Efficacy of dietary instructions in newly diagnosed non-insulin-dependent diabetic patients.
Comparison of two different patient education regimens. Acta Med Scand 222: 323-331

16. Faber OK, Binder C (1977) C-peptide response to glucagon: a test for the residual B-cell function in diabetes mellitus. Diabetes 26: $605-610$

17. Bottazzo GF, Florin-Christensen A, Doniach D (1974) Islet cell antibodies in diabetes mellitus with autoimmune polyendocrine deficiencies. Lancet II: 1279-1282

18. Bottazzo GF, Dean BM, Gorsuch AN, Cudworth AG, Doniach D (1980) Complement-fixing islet cell antibodies in type 1 diabetes: possible monitors of active beta-cell damage. Lancet I: $668-672$

19. Karjalainen JK (1990) Islet cell antibodies as predictive markers for IDDM in normal children with a high background incidence of the disease. Diabetes 39: 1144-1150

20. Bonifacio E, Dawkins RL, Lernmark $\AA$ (1987) Immunology and Diabetes Workshops. Report on the Second International Workshop on the Standardisation of cytoplasmic islet cell antibodies. Diabetologia 30: 273

21. Uusitupa M (1983) Coronary heart disease and left ventricular performance in newly diagnosed non-insulin-dependent diabetics. Publications of the University of Kuopio. Series Original Reports 6 Kuopio (Dissertation)

22. Bellis A, Bizzarro A, Iacono G, Marfella A, Russo M, Cacciatore L (1988) Islet cell antibodies and serum neopterin levels in Type 2 (non-insulin-dependent) diabetes: a 2 -year retrospective study. Diabetologia 31:125 (Abstract)

23. Spencer KM, Tarn AC, Dean BM, Lister J, Bottazzo GF (1984) Fluctuating islet-cell auto-immunity in unaffected relatives of patients with insulin-dependent diabetes. Lancet I: 764-766

24. Srikanta S, Ganda OP, Jackson RA, Bring SJ, Fleischnick E, Yunis E, Alper C, Soeldner JS, Eisenbarth GS (1984) Pre-Type 1 (insulin-dependent) diabetes: common endocrinological course despite immunological and immunogenetic heterogeneity. Diabetologia 27: 146-148

25. Kobayashi T, Itoh T, Kosaka K, Sato K, Tsuji K (1987) Time course of islet cell antibodies and B-cell function in non-insulindependent stage of type 1 diabetes. Diabetes 36:510-517

26. Groop L, Miettinen A, Groop P-H, Meri S, Koskimies S, Bottazzo GF (1988) Organ-specific autoimmunity and HLA-DR antigens as markers for B-cell destruction in patients with type II diabetes. Diabetes 37: 99-103

27. Lendrum R, Walker G, Gamble DR (1975) Islet-cell autoantibodies in juvenile diabetes mellitus of recent onset. Lancet I: $880-883$

28. Eisenbarth GS (1986) Type 1 diabetes mellitus. A chronic autoimmune disease. N Engl J Med 314: 1360-1368

29. Karjalainen J, Salmela P, Ilonen J, Surcel H-M, Knip M (1989) A comparison of childhood and adult Type 1 diabetes mellitus. $\mathrm{N}$ Engl J Med 320:881-886

30. Lev-Ran A, Hill LR (1987) Different body-fat distributions in IDDM and NIDDM. Diabetes Care 10: 491-494

31. Gray RS, Irvine WJ, Cameron EHD, Duncan LJP (1980) Glucose and insulin responses to oral glucose in non-insulin-dependent diabetics with and without the islet cell antibody. Diabetes $29: 312-316$

Received: 13 July 1990

and in revised form: 11 January 1991

\section{Dr. L. Niskanen}

Department of Medicine

University of Kuopio

SF-70210 Kuopio

Finland 